\title{
Combined stimuli of cold, hypoxia, and dehydration status on body temperature in rats: a pilot study with practical implications for humans
}

Tadashi Uno ${ }^{\dagger}$, Tatsuya Hasegawa and Masahiro Horiuchi ${ }^{*+}[$

\begin{abstract}
Objective: As human thermoregulatory responses to maintain core body temperature ( $\left.T_{\text {core }}\right)$ under multiple stressors such as cold, hypoxia, and dehydration (e.g., exposure to high-altitude) are varied, the combined effects of cold, hypoxia, and dehydration status on $\mathrm{T}_{\text {core }}$ in rats were investigated. The following environmental conditions were constructed: (1) thermoneutral $\left(24^{\circ} \mathrm{C}\right)$ or cold $\left(10^{\circ} \mathrm{C}\right),(2)$ normoxia $\left(21 \% \mathrm{O}_{2}\right)$ or hypoxia $\left(12 \% \mathrm{O}_{2}\right)$, and (3) euhydration or dehydration ( $48 \mathrm{~h}$ water deprivation), resulted in eight environmental conditions [2 ambient temperatures $\left(\mathrm{T}_{\mathrm{a}}\right) \times 2$ oxygen levels $\times 2$ hydration statuses)]. Each condition lasted for $24 \mathrm{~h}$.
\end{abstract}

Results: Normoxic conditions irrespective of hypoxia or dehydration did not strongly decrease the area under the curve (AUC) in $T_{\text {core }}$ during the 24 period, whereas, hypoxic conditions caused greater decreases in the AUC in $T_{\text {core' }}$ which was accentuated with cold and dehydration $\left(\mathrm{T}_{\mathrm{a}} \times \mathrm{O}_{2} \times\right.$ hydration, $P=0.040$ by three-way ANOVA). In contrast, multiple stressors $\left(\mathrm{T}_{\mathrm{a}} \times \mathrm{O}_{2} \times\right.$ hydration or $\mathrm{T}_{\mathrm{a}} \times \mathrm{O}_{2}$ or $\mathrm{O}_{2} \times$ hydration or $\mathrm{T}_{\mathrm{a}} \times$ hydration) did not affect locomotor activity counts (all $P>0.05$ ), but a significant simple main effect for $\mathrm{O}_{2}$ and $\mathrm{T}_{\mathrm{a}}$ was observed $(P<0.001)$. Heat loss index was not affected by all environmental conditions (all $P>0.05$ ). In conclusion, decreases in $T_{\text {core }}$ were most affected by multiple environmental stressors such as cold, hypoxia, and dehydration.

Keywords: Area under the curve, Heat loss index, High-altitude, Hypothermia, Metabolism, Set point

\section{Introduction}

Most of mammal's (including human) energy regulates core body temperature $\left(\mathrm{T}_{\text {core }}\right)$. Various environmental factors such as heat, cold, hypoxia, humidity, or wind would affect $\mathrm{T}_{\text {core }}$. Although physiological adaptation to environmental stressors is often studied in isolation, these stressors are frequently combined outside of laboratory settings. At high altitudes, both barometric

\footnotetext{
*Correspondence: mhoriuchi@mfri.pref.yamanashi.jp
}

TTadashi Uno and Masahiro Horiuchi equally contributed to this study Division of Human Environmental Science, Mount Fuji Research Institute, Kami-yoshida 5597-1, Fuji-yoshida-city, Yamanashi 4030005, Japan pressure and ambient temperature $\left(\mathrm{T}_{\mathrm{a}}\right)$ decreases with an increase in altitude.

Cold exposure reduces human cutaneous blood flow that decreases heat transfer from the core to peripheral tissues [1]. This decreases in skin temperature, which narrows the gradient for cutaneous heat loss, and promotes heat conservation, and is vital to the prevention of hypothermia in cold. Contrariwise, hypoxic conditions reduce metabolism and core body temperature $\left(\mathrm{T}_{\text {core }}\right)$ in many small mammals [2], primates [3], and humans [4-7]. In humans, this may be explained by peripheral circulation. Simulated high altitude elicits a cutaneous hyperemia that is mediated at the tissue level $[8,9]$, suggesting an acceleration in the rate of core cooling. The combined

(c) The Author(s) 2020. This article is licensed under a Creative Commons Attribution 4.0 International License, which permits use, sharing, adaptation, distribution and reproduction in any medium or format, as long as you give appropriate credit to the original author(s) and the source, provide a link to the Creative Commons licence, and indicate if changes were made. The images or other third party material in this article are included in the article's Creative Commons licence, unless indicated otherwise in a credit line to the material. If material is not included in the article's Creative Commons licence and your intended use is not permitted by statutory regulation or exceeds the permitted use, you will need to obtain permission directly from the copyright holder. To view a copy of this licence, visit http://creativeco mmons.org/licenses/by/4.0/. The Creative Commons Public Domain Dedication waiver (http://creativecommons.org/publicdomain/ zero/1.0/) applies to the data made available in this article, unless otherwise stated in a credit line to the data. 
effects of cold and hypoxia may have competing effects on cutaneous circulation, and hence, $\mathrm{T}_{\text {core }}$ changes would be complicated. There are several issues to consider when investigating the combined effects of cold and hypoxia on $\mathrm{T}_{\text {core }}$ and/or peripheral circulation in humans. Previous human studies of cold and hypoxia have been conducted in a relatively short period (within $2 \mathrm{~h}$ ) [9-13]. Generally, when humans are exposed to high-altitude such as climbing a mountain, exposure of several hours or a few days can occur. Thus, it may be difficult to expose people to multiple environmental stressors for a longer time due to ethical problems and strain on the participants. Importantly, greater individual variances in response to multiple stressors, i.e., cold and hypoxia, exist in humans [13]. Specifically, changes in $\mathrm{T}_{\text {core }}$ under exposure to hypoxia in cold stress cannot be explained by only peripheral circulation [13]. An initial step using animal modes (considered to have less individual variance), is required.

As heat dissipation caused by fluid redistribution is important in thermoregulation, the hydrations status on $\mathrm{T}_{\text {core }}$ should also be considered. For example, hyperventilation-induced dehydration is observed at highaltitude [14]. Similarly, inhalation of hypoxic gas causes an increase in urine volume, also suggesting dehydration status [15]. However, little is known about the combined effects of cold, hypoxia, and hypohydration on $\mathrm{T}_{\text {core }}$ irrespective of whether in humans or animals.

Accordingly, the main aim of this pilot study was to investigate the combined effect of cold, hypoxia, and dehydration on $\mathrm{T}_{\text {core }}$ and related factors using animal models. We hypothesized that multiple stimuli (cold, hypoxia, and dehydration) would cause the greatest reductions in $\mathrm{T}_{\text {core }}$.

\section{Main text Methods \\ Animals}

Experiments were performed using age-matched (1014 weeks), male, Wistar rats weighing $250-320 \mathrm{~g}(\mathrm{n}=40)$. Animals were maintained in a temperature-controlled ambient temperature $\left(\mathrm{T}_{\mathrm{a}}=24{ }^{\circ} \mathrm{C}\right)$ and relative humidity (50\%), fed ad libitum, and kept on a $12 \mathrm{~h}$ light-dark cycle. All experiments were performed in accordance with the Ethics Committee for Animal Experiments, Mount Fuji Research Institute, Yamanashi Prefecture Government (ECAE-03-2016).

\section{Experimental procedures}

Environmental conditions were as follows; (1) thermoneutral $\left(24{ }^{\circ} \mathrm{C} \mathrm{T}_{\mathrm{a}}\right)$ or cold $\left(10{ }^{\circ} \mathrm{C} \mathrm{T} \mathrm{a}\right)$, (2) normoxia $\left(21 \% \mathrm{O}_{2}\right.$; room air) or normobaric hypoxia $\left(12 \% \mathrm{O}_{2}\right)$, (3) euhydration (48 $\mathrm{h}$ ad libitum access to water before the experiment) or dehydration ( $48 \mathrm{~h}$ water deprivation before the experiment) (Fig. 1). In previous studies, $5{ }^{\circ} \mathrm{C} \mathrm{T}_{\mathrm{a}}[16,17]$ or $10{ }^{\circ} \mathrm{C} \mathrm{T}_{\mathrm{a}}$ [18], and $10 \% \mathrm{O}_{2}[16,19,20]$ or $7-10-12 \% \mathrm{O}_{2}$ [21] were used. In our preliminary experiments, a few rats fell into asphyxia condition under $5{ }^{\circ} \mathrm{C}$, therefore, we conducted the experiment of $10{ }^{\circ} \mathrm{C} \mathrm{T}_{\mathrm{a}}$. Regarding to $\mathrm{O}_{2}$ concentration, $\mathrm{O}_{2}$ saturation acutely decrease around below 50-60 torr $\mathrm{PO}_{2}$, at which is almost equivalent to $12 \% \mathrm{O}_{2}$, based on oxygen-hemoglobin dissociation curve [22]. To produce dehydration status, $48 \mathrm{~h}$ water deprivation was enforced before the experiment, and the experiment lasted $24 \mathrm{~h}$, resulted in $72 \mathrm{~h}$ water deprivation [23]. Eight experiments $\left(2 \mathrm{~T}_{\mathrm{a}} \times 2\right.$ oxygen $\times 2$ hydration status $=8$ conditions; $\mathrm{n}=5$ for each) were performed. Ambient temperature $\left(24^{\circ} \mathrm{C}\right.$ or $\left.10^{\circ} \mathrm{C}\right)$ was maintained in a climatic chamber (MIR-153; SANYO Electric Co., Ltd, Japan). The oxygen concentrations in the vinyl tent surrounding the climatic chamber were set at normobaric normoxia $\left(21 \% \mathrm{O}_{2}\right)$ or hypoxia $\left(12 \% \mathrm{O}_{2}\right)$. Hypoxic gas $\left(12 \% \mathrm{O}_{2}\right)$ was supplied via a generator (Hypoxico Everest Summit II; Will Co., Ltd., Tokyo, Japan) and oxygen concentration was verified before and after each experiment (AE-300; Minato Medical Science, Osaka, Japan). The rats were weighed before and after the experiment.

\section{General surgical preparation}

Before the experiment, animals were anesthetized with an anesthetic mixture of medetomidine, midazolam, and butorphanol. For the measurements of $\mathrm{T}_{\text {core }}$, a radio transmitter $(15 \times 30 \times 8 \mathrm{~mm}$; Physio Tel TA10TA-F40, Data Sciences International Co., Ltd., St. Paul, MN, USA) was placed in the abdominal cavity of each rat. The rats were allowed to recover for at least one week before

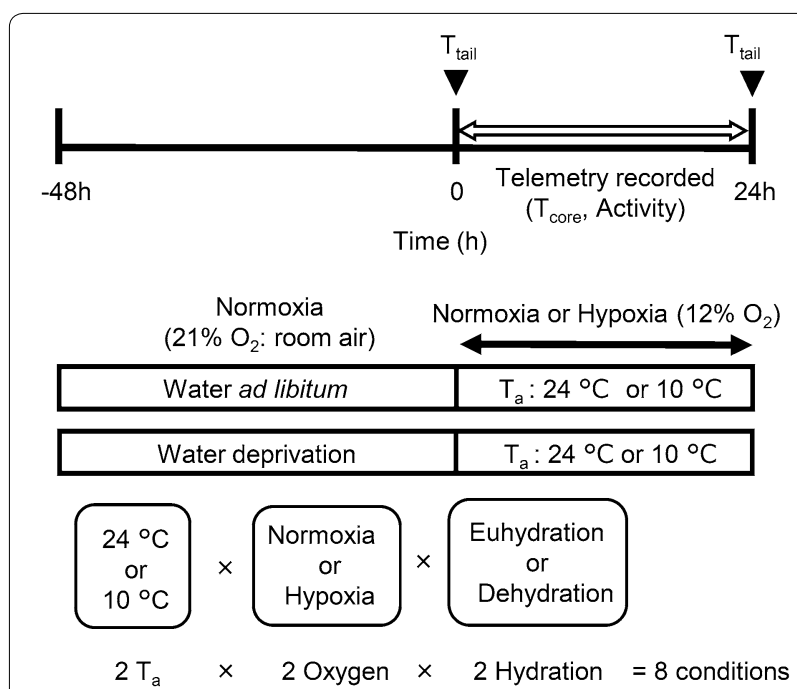

Fig. 1 Experimental protocols. $T_{\text {core' }}$ core temperature; $T_{\text {tail, }}$ skin temperature of the tail; $T_{a^{\prime}}$ ambient temperature 
measurements. After each experiment, a radio transmitter was taken under anesthesia, thereafter, exsanguination from a cut through the heart aorta was applied for euthanization.

\section{Measurements}

In addition to the measurement of $\mathrm{T}_{\text {core }}$, infrared thermography (Thermo Shot F30; NEC Avio Infrared Technologies Co., Ltd., Japan) was used to measure tail skin temperature $\left(\mathrm{T}_{\text {tail }}\right)$. Counts of locomotor activity (an indicator of behavior) were recorded every minute with a data collection system, which consisted of a receiver board (model RLA2000, Data Sciences International, Co., LTD, St. Paul, MN, USA) under the cage connected to a personal computer. The locomotor activity counts reflected positional movements but did not show other movements such as grooming or food intake.

\section{Data analysis}

The area under the curve (AUC; $0-24 \mathrm{~h}$ ) of $\mathrm{T}_{\text {core }}$ was calculated from values measured at $0 \mathrm{~h}$, using data every $1 \mathrm{~min}$ and the trapezoidal method. $\mathrm{T}_{\text {tail }}$ was the averaged values from the first and second thirds of the tail. Heat Loss Index (HLI) as an indicator of peripheral vasomotor activity, was calculated using the following equation:

$$
\text { Heat Loss Index }(H L I)=\frac{\left(T_{\text {tail }}-T_{a}\right)}{\left(T_{\text {core }}-T_{a}\right)}
$$

The value of HLI ranges from 0 (full vasoconstriction) to 1 (full vasodilation).

Changes in HLI $(\Delta \mathrm{HLI})$ were calculated by the difference between pre (time $=0 \mathrm{~h}$ )- and post (time $=24 \mathrm{~h}$ )exposure to each environmental condition [24].

\section{Statistics}

Values are represented as mean \pm standard deviation. All statistics were performed using a $\mathrm{R}$ software (ver. 3.1.3). A three-way ANOVA $\left(\mathrm{T}_{\mathrm{a}} \times \mathrm{O}_{2} \times\right.$ Hydration) was performed for comparisons of the AUC, HLI, and activity counts. If significant $F$ values were obtained, Bonferroni's post-hoc test was used for further comparisons. A $P$ value $<0.05$ was defined as statistically significant.

\section{Results}

Dehydration status (irrespective of $\mathrm{T}_{\mathrm{a}}$ or $\mathrm{O}_{2}$ conditions) decreased body weight compared with the control conditions $\left(24{ }^{\circ} \mathrm{C} \mathrm{T}, 21 \% \mathrm{O}_{2}\right.$, and euhydration) $(\mathrm{F}=95.99$, $P<0.001$ ] (Additional file 1: Table S1). Conversely, hypoxia or cold per se did not affect body weight changes.

Mean values of $\mathrm{T}_{\text {core }}$ in each condition and comparisons of the $\mathrm{T}_{\text {core }}$ AUC are shown in Fig. 2. To avoid difficulties of observation in time course changes in $\mathrm{T}_{\text {core, }}$, mean values without SD are shown (Fig. 2a). Normoxic
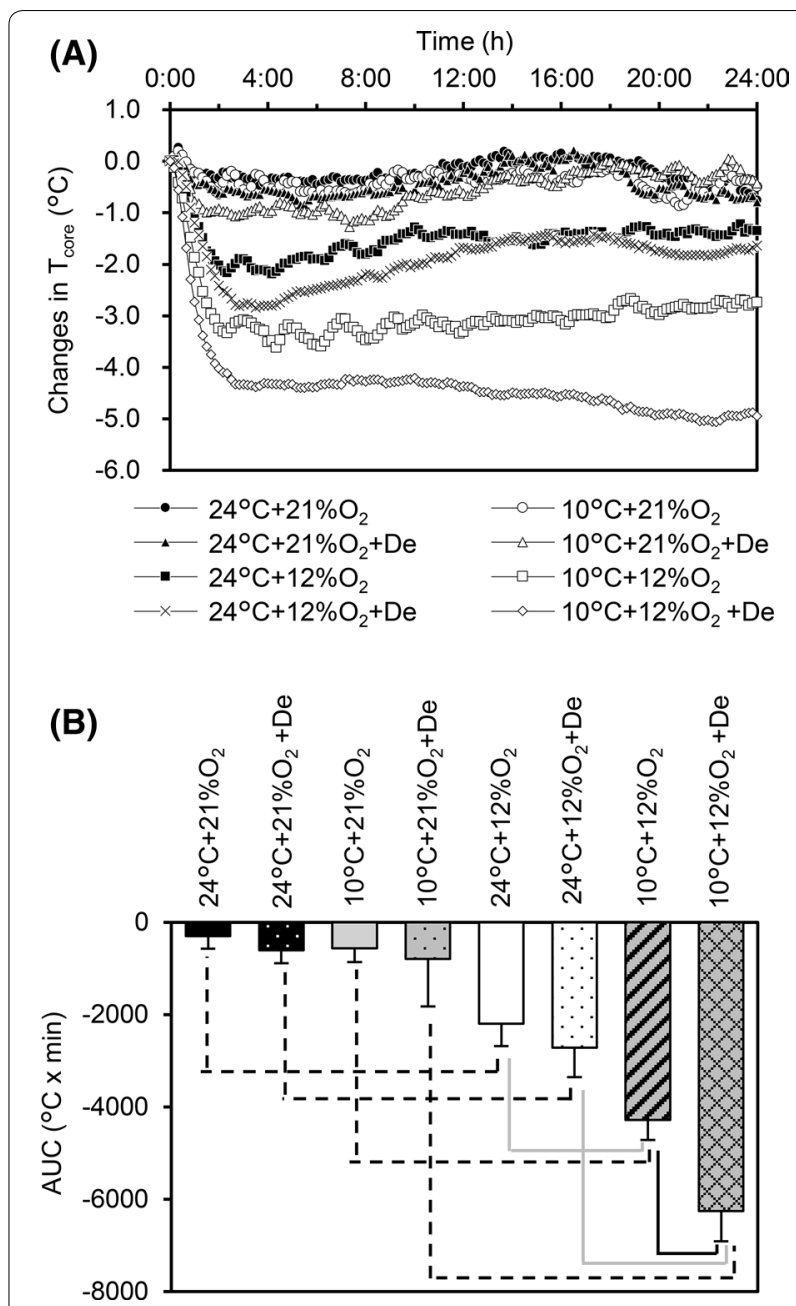

Fig. 2 Time course of $T_{\text {core }}$ among different environmental conditions. Values are given as only means ( $n=5$ for each, a). Mean values of the area under the curve (AUC) with standard deviation (SD) among all conditions throughout the $24 \mathrm{~h}$ experimental period (b). Hypoxia significantly decreased the AUC irrespective of cold and dehydration (dashed black lines). In hypoxia, cold environment $\left(10^{\circ} \mathrm{C}\right)$ further decreased the AUC in both euhydration and dehydration conditions (solid gray lines). Dehydration affected the AUC only in both hypoxia and cold (solid black line)

conditions (irrespective of hypoxia or dehydration) did not decrease the AUC, whereas, hypoxic conditions caused greater decreases in the AUC, and were accentuated with cold and dehydration. A second-order interaction $\left(\mathrm{T}_{\mathrm{a}} \times \mathrm{O}_{2} \times\right.$ hydration) was observed by three-way ANOVA ( $\mathrm{F}=4.570, P=0.040$, Fig. $2 \mathrm{~b})$. Figure 3a shows comparisons of activity in each condition. A three-way ANOVA revealed a trend in a second-order interaction $\left(\mathrm{T}_{\mathrm{a}} \times \mathrm{O}_{2} \times\right.$ hydration; $\left.\mathrm{F}=4.066, P=0.052\right)$, while no significant simple interactions were observed $\left(\mathrm{T}_{\mathrm{a}} \times \mathrm{O}_{2}\right.$; $\mathrm{F}=0.011, P=0.918, \mathrm{O}_{2} \times$ hydration; $\mathrm{F}=0.065, P=0.800$, 


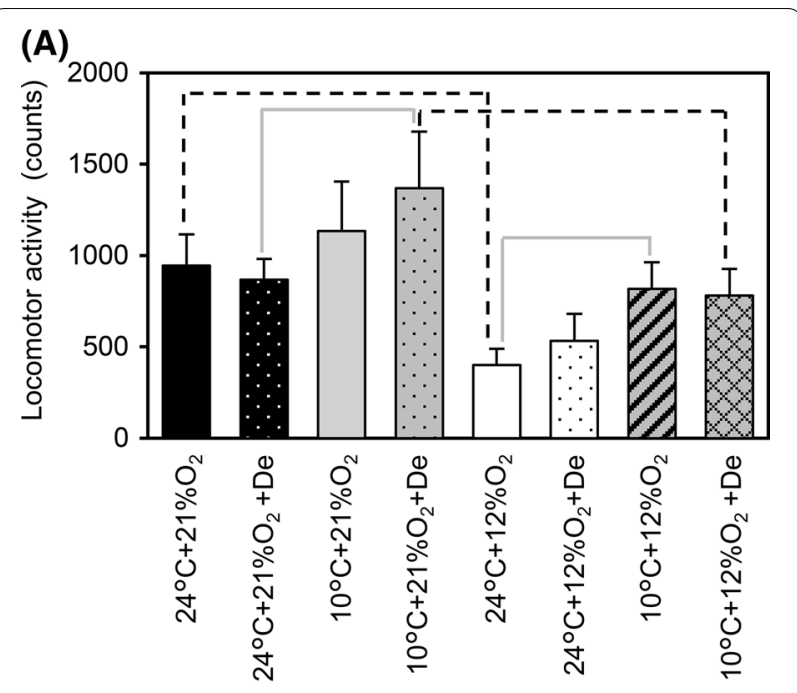

(B)

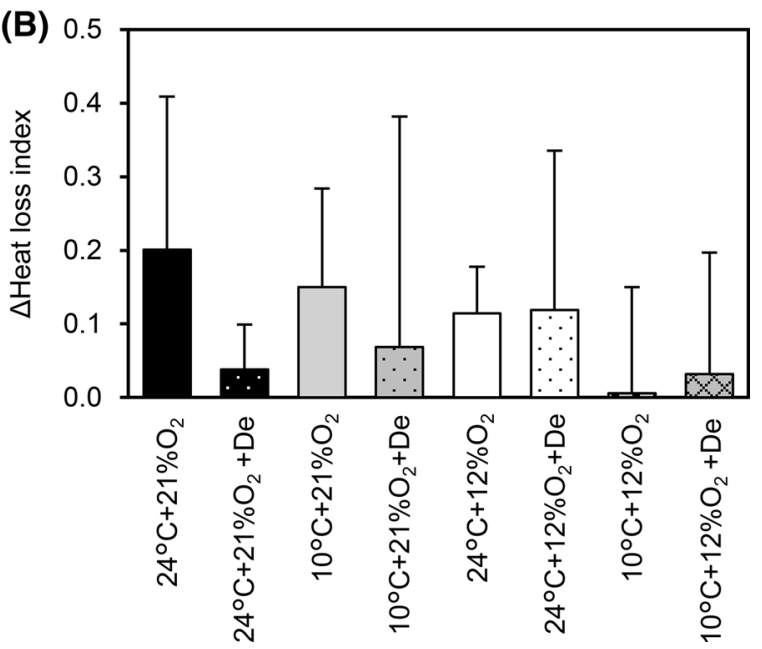

Fig. 3 Mean values of the locomotor activity with SD among all conditions throughout the $24 \mathrm{~h}$ experimental period (a). Hypoxia significantly decreased the locomotor activity irrespective of cold and dehydration (dashed black lines). Dashed black and solid gray lines indicate significant differences when considering a simple main effect for oxygen and $T_{a}$. Mean values of the heat loss index with SD among all conditions throughout the $24 \mathrm{~h}$ experimental period (b)

$\mathrm{T}_{\mathrm{a}} \times$ hydration; $\left.\mathrm{F}=0.357, P=0.554\right)$. A simple main effect of $\mathrm{O}_{2}$ and $\mathrm{T}_{\mathrm{a}}$ was observed $\left(\mathrm{T}_{\mathrm{a}} ; \mathrm{F}=32.30, \mathrm{O}_{2}\right.$; $\mathrm{F}=56.202, P<0.001)$. Comparisons in HLI under all conditions showed no significant differences in the simple main effect, a simple interaction, and second order interaction were observed (all $P>0.05$ ) (Fig. 3b).

\section{Discussion}

The major findings of this pilot study were two-fold: (1) the AUC of $\mathrm{T}_{\text {core }}$ was mostly affected by multiple stressors (cold, hypoxia, and dehydration), (2) activity counts and HLI were not affected by multiple stressors.
The $\mathrm{T}_{\text {core }}$ decreased slightly within a few hours in normoxia (about -0.1 to $-0.5{ }^{\circ} \mathrm{C}$ decrease per hour); however, these initial reductions in the $\mathrm{T}_{\text {core }}$ were markedly greater under hypoxia (about -1 to $-2.5{ }^{\circ} \mathrm{C}$ decrease per hour). During acute exposure to a cold environment, shivering thermogenesis is activated to augment heat production $[18,25,26]$, compensating for the increase in heat loss that occurs at low $\mathrm{T}_{\mathrm{a}}$. In rats, shivering thermogenesis is gradually replaced by non-shivering thermogenesis during cold acclimation (four weeks) [27], which allows the animal to maintain high body temperatures under low $\mathrm{T}_{\mathrm{a}}$ conditions. In the present experiment, as exposure time was $24 \mathrm{~h}$, both shivering and non-shivering thermogenesis may have contributed to maintain $\mathrm{T}_{\text {core }}$ during the $24 \mathrm{~h}$ period under normoxic conditions, irrespective of $\mathrm{T}_{\mathrm{a}}$ and dehydration, although the precise mechanisms are unclear. In hypoxia, a similar initial decrease in $\mathrm{T}_{\text {core }}$ has been observed $[20,28]$, and it is generally a consequence of a decrease in the $\mathrm{T}_{\text {core }}$ set-points, known as hypoxia-induced anapyrexia [29-31]. Therefore, these greater reductions in set-point in hypoxia may be associated with non-recovery in $\mathrm{T}_{\text {core }}$ after a $24 \mathrm{~h}$ period. A continuously lower $\mathrm{T}_{\text {core }}$ after an initial phase of $24 \mathrm{~h}$ may be explained by several candidates, such as hypoxic-induced hypometabolism [32-34], or nitric oxide pathway -involved mechanisms on thermoregulation [35, 36]. Moreover, effects of acute exposure to hypoxia on $\mathrm{T}_{\text {core }}$ has also been demonstrated to be strongly affected by $\mathrm{T}_{\mathrm{a}}[19,34]$. Yet, it is still unclear why combined effects of cold, hypoxia, and dehydration had the most impact on the lowest AUC of $\mathrm{T}_{\text {core }}$ compared with other seven environmental conditions. One possible explanation is a loss of plasma volume with $48 \mathrm{~h}$ water deprivation before the main experiment. A previous study reported an initial increase in body surface temperature during hypoxia, and hence an initial increase in peripheral blood flow during hypoxia may indicate the shifting of heat away from the core to the periphery to facilitate cooling [34]. If this hypothesis were true despite dehydration status in this experiment, blood flow redistribution from core to peripheral tissues might dominate peripheral tissues to core transfer for protection in $T_{\text {core }}$ decreases, and hence, $T_{\text {core }}$ further decreases under combined conditions (cold, hypoxia, and dehydration). This hypothesis is speculative, and further experiments are needed.

Regarding to activity counts, significant main effects were found for oxygen and $\mathrm{T}_{\mathrm{a}}$. Specifically, $\mathrm{T}_{\mathrm{a}}$ of $24{ }^{\circ} \mathrm{C}$ or a hypoxic condition showed significantly lower values for activity counts. These results cincture with a previous study, showing activity counts decreased with $\mathrm{T}_{\mathrm{a}}$ increase and an observation of hypoxic-induced lower locomotor activity counts [19]. Unexpectedly, none of the 
environmental conditions affect HLI. Some methodological consideration should occur. HLI was evaluated at the start and the end of the $24 \mathrm{~h}$ period, and therefore, continuous assessment of HLI will be investigated in future studies.

Our findings may be informative for populations who are working and performing in severe environmental conditions (i.e., cold and hypoxia), Specifically, humans cannot control environmental conditions; however, as dehydration status may cause further reductions in $\mathrm{T}_{\text {core, }}$, an appropriate beverage intake could be effective tactics.

In summary, multiple environmental stressors (cold, hypoxia, and dehydration) have the most impact on the lower $\mathrm{T}_{\text {core, }}$ as observed in the rats in this experiment. Moreover, locomotor activity counts and HLI do not affect this lower $\mathrm{T}_{\text {core }}$.

\section{Limitations}

There are several limitations in the study. Firstly, the small size ( $\mathrm{n}=5$ for each) should be re-considered. A poshoc power analysis for pairwise comparisons with significant difference (i.e., $\mathrm{T}_{\text {core }} \mathrm{AUC}$ ) was used as the standard of $80 \%$ power with a two-sided significance level of 0.05 (G Power 3.1). When considering each simple main effect of cold, hypoxia, or dehydration, a sample size of three in each group was necessary to achieve the appropriate statistical power for significant comparisons (Fig. 2b). However, more than 20 for each condition would have been necessary for other non-significant comparisons. Second, to clarify the underlying precise mechanisms of the lowest $\mathrm{T}_{\text {core }}$ with the combined effects, the metabolic rate (oxygen consumption), and HLI should have been measured continuously and other influencing factors on thermoregulation or body fluid regulatory hormones (e.g., thyroid hormone, noradrenaline, glucagon, renin, aldosterone, and vasopressin) should have been measured.

\section{Supplementary information}

Supplementary information accompanies this paper at https://doi. org/10.1186/s13104-020-05375-w.

Additional file 1. Supplemental table. Body weight (BW) changes 48 hours before the experiment and just before the main experiment $(24 \mathrm{~h}$ exposure) in each condition.

\section{Abbreviations}

AUC: Area under the curve; HLI: Heat loss index; $T_{a}$ : Ambient temperature; $T_{\text {core: }}$ : Core temperature.

\section{Acknowledgements}

The authors would like to thank Editage (www.ediatge.jp/) for the English language service.

\section{Authors' contributions}

$\mathrm{TU}, \mathrm{TH}$, and MH conceived the design and concept. TU performed all experiments. TU, TH and MH analyzed and interrupted the data. TU prepared table and figures. TU and $\mathrm{MH}$ drafted the first manuscript. TU, TH and MH edited and revised the manuscript. All authors read and approved the final manuscript.

\section{Funding}

This research was supported by a grant in Japan Society for the Promotion of Science (No. 26440268 to M.H.).

\section{Availability of data and materials}

The datasets used and/or analyzed during the current study are available from the corresponding author on reasonable request.

Ethics approval and consent to participate

All experiment procedures were approved by the Animal Experiment Ethics Committee at Mount Fuji Research Institute.

\section{Consent for publication}

Not appreciable.

\section{Competing interests}

The authors declare that they have no competing interests.

Received: 18 August 2020 Accepted: 5 November 2020

Published online: 11 November 2020

\section{References}

1. Charkoudian N. Skin blood flow in adult human thermoregulation: how it works, when it does not, and why. Mayo Clin Proc. 2003;78(5):603-12.

2. Frappell P, Lanthier C, Baudinette RV, Mortola JP. Metabolism and ventilation in acute hypoxia: a comparative analysis in small mammalian species. Am J Physiol. 1992;262(6 Pt 2):R1040-6.

3. Tattersall GJ, Blank JL, Wood SC. Ventilatory and metabolic responses to hypoxia in the smallest simian primate, the pygmy marmoset. J Appl Physiol. 2002;92(1):202-10.

4. Cipriano LF, Goldman RF. Thermal responses of unclothed men exposed to both cold temperatures and high altitudes. J Appl Physiol. 1975;39(5):796-800.

5. Johnston CE, White MD, Wu M, Bristow GK, Giesbrecht GG. Eucapnic hypoxia lowers human cold thermoregulatory response thresholds and accelerates core cooling. J Appl Physiol. 1996;80(2):422-9.

6. Kottke FJ, Phalen JS, et al. Effect of hypoxia upon temperature regulation of mice, dogs, and man. Am J Physiol. 1948;153(1):10-5.

7. Nair CS, George S. The effect of altitude and cold on body temperature during acclimatization of man at $3300 \mathrm{~m}$. Int J Biometeorol. 1972;16(1):79-84.

8. Anderson D, Nagasawa G, Norfleet W, Olszowka A, Lundgren C. O2 pressures between 0.12 and $2.5 \mathrm{~atm}$ abs, circulatory function, and N2 elimination. Undersea Biomed Res. 1991;18(4):279-92.

9. Simmons GH, Minson CT, Cracowski JL, Halliwill JR. Systemic hypoxia causes cutaneous vasodilation in healthy humans. J Appl Physiol. 2007;103(2):608-15.

10. Keramidas ME, Kolegard R, Mekjavic IB, Eiken O. Acute effects of normobaric hypoxia on hand-temperature responses during and after local cold stress. High Alt Med Biol. 2014;15(2):183-91.

11. Keramidas ME, Kolegard R, Mekjavic IB, Eiken O. Interactions of mild hypothermia and hypoxia on finger vasoreactivity to local cold stress. Am J Physiol Regul Integr Comp Physiol. 2019;317(3):R418-31.

12. O'Brien C, Castellani JW, Muza SR. Acute hypobaric hypoxia effects on finger temperature during and after local cold exposure. High Alt Med Biol. 2015;16(3):244-50.

13. Simmons GH, Barrett-O'Keefe Z, Minson CT, Halliwill JR. Cutaneous vascular and core temperature responses to sustained cold exposure in hypoxia. Exp Physiol. 2011;96(10):1062-71.

14. Kayser B. Nutrition and energetics of exercise at altitude. Theory and possible practical implications. Sports Med. 1994;17(5):309-23.

15. Swenson ER, Duncan TB, Goldberg SV, Ramirez G, Ahmad S, Schoene RB. Diuretic effect of acute hypoxia in humans: relationship to hypoxic 
ventilatory responsiveness and renal hormones. J Appl Physiol. 1995;78(2):377-83.

16. Cadena V, Tattersall GJ. Body temperature regulation during acclimation to cold and hypoxia in rats. J Therm Biol. 2014;46:56-64.

17. Dzal YA, Milsom WK. Hypoxia alters the thermogenic response to cold in adult homeothermic and heterothermic rodents. J Physiol. 2019;597(18):4809-29.

18. Griggio MA. The participation of shivering and nonshivering thermogenesis in warm and cold-acclimated rats. Comp Biochem Physiol A Comp Physiol. 1982;73(3):481-4.

19. Bishop B, Silva G, Krasney J, Nakano H, Roberts A, Farkas G, et al. Ambient temperature modulates hypoxic-induced changes in rat body temperature and activity differentially. Am J Physiol Regul Integr Comp Physiol. 2001;280(4):R1190-6.

20. Bishop B, Silva G, Krasney J, Salloum A, Roberts A, Nakano H, et al. Circadian rhythms of body temperature and activity levels during $63 \mathrm{~h}$ of hypoxia in the rat. Am J Physiol Regul Integr Comp Physiol. 2000;279(4):R1378-85.

21. Tattersall GJ, Milsom WK. Hypoxia reduces the hypothalamic thermogenic threshold and thermosensitivity. J Physiol. 2009:587(Pt 21):5259-74.

22. Roach RC. Cardiovascular regulation during hypoxia. In: Saltin B, Boushel $\mathrm{R}$, Secher NH, Mitchell J, editors. Exercise and circulation in health and disease. Champaign, IL: Human Kinetics; 2000. p. 177-94.

23. Tamura Y, Mori N, Xu B, Nakamura T, Yamakoshi S, Hirose T, et al. Water deprivation increases (Pro)renin receptor levels in the kidney and decreases plasma concentrations of soluble (Pro)renin receptor. Tohoku J Exp Med. 2016;239(3):185-92.

24. Romanovsky AA, Ivanov Al, Shimansky YP. Selected contribution: ambient temperature for experiments in rats: a new method for determining the zone of thermal neutrality. J Appl Physiol. 2002;92(6):2667-79.

25. Sessler DI. Thermoregulatory defense mechanisms. Crit Care Med. 2009:37(7 Suppl):S203-10.

26. Tikuisis P, Bell DG, Jacobs I. Shivering onset, metabolic response, and convective heat transfer during cold air exposure. J Appl Physiol. 1991;70(5):1996-2002.
27. Depocas F, Hart JS, Heroux O. Cold acclimation and the electromyogram of unanesthetized rats. J Appl Physiol. 1956;9(3):404-8.

28. Mortola JP, Seifert EL. Hypoxic depression of circadian rhythms in adult rats. J Appl Physiol. 2000;88(2):365-8.

29. Mayfield KP, Hong EJ, Carney KM, D'Alecy LG. Potential adaptations to acute hypoxia: Hct, stress proteins, and set point for temperature regulation. Am J Physiol. 1994;266(5 Pt 2):R1615-22.

30. Steiner AA, Branco LG. Hypoxia-induced anapyrexia: implications and putative mediators. Annu Rev Physiol. 2002:64:263-88.

31. Steiner AA, Rocha MJ, Branco LG. A neurochemical mechanism for hypoxia-induced anapyrexia. Am J Physiol Regul Integr Comp Physiol. 2002;283(6):R1412-22.

32. Barros RC, Zimmer ME, Branco LG, Milsom WK. Hypoxic metabolic response of the golden-mantled ground squirrel. J Appl Physiol. 2001;91(2):603-12.

33. Rohlicek CV, Saiki C, Matsuoka T, Mortola JP. Oxygen transport in conscious newborn dogs during hypoxic hypometabolism. J Appl Physiol. 1998;84(3):763-8.

34. Tattersall GJ, Milsom WK. Transient peripheral warming accompanies the hypoxic metabolic response in the golden-mantled ground squirrel. J Exp Biol. 2003;206(Pt 1):33-42.

35. Branco LG, Carnio EC, Barros RC. Role of the nitric oxide pathway in hypoxia-induced hypothermia of rats. Am J Physiol. 1997;273(3 Pt 2):R967-71.

36. Fabris G, Anselmo-Franci JA, Branco LG. Role of nitric oxide in hypoxiainduced hyperventilation and hypothermia: participation of the locus coeruleus. Braz J Med Biol Res. 1999:32(11):1389-98.

\section{Publisher's Note}

Springer Nature remains neutral with regard to jurisdictional claims in published maps and institutional affiliations.
Ready to submit your research? Choose BMC and benefit from:

- fast, convenient online submission

- thorough peer review by experienced researchers in your field

- rapid publication on acceptance

- support for research data, including large and complex data types

- gold Open Access which fosters wider collaboration and increased citations

- maximum visibility for your research: over $100 \mathrm{M}$ website views per year

At BMC, research is always in progress.

Learn more biomedcentral.com/submissions 